\title{
THE VALUE AND MYSTERY OF THE BODY IN FULFILLING THE HUMAN AS ASPECTS OF THE ICONIC ANTROPOLOGY INSIDE OF THE THEOLOGY OF THE SCYTHIAN MONKS
}

Lucian-Dumitru COLDA*

\begin{abstract}
Starting from the wording Unus de Trinitatepassusest carne, the present study aims to discover through the Christology of the Scythian monks (Dacian-Romans) those essential elements of the iconic anthropology that make transparent the theological perspective of assuming the human body by the Divine Logos who, by becoming human, became His body forever, to shine through it the light and the life of the divinity in the epectasis process of deification. Thus the value and the mystery of the body illustrates the fulfillment of the human as an essential factor in the theological thinking referring to the possibility of the iconographic representation of the Son of God, of God's Mother, of the saints and of the deifying events in the economy of the salvation.
\end{abstract}

Keywords:Unus de Trinitatepassusest carne, Scythian monks (DacianRomans), the human body, Christology, iconic anthropology.

\section{Prolegomena}

Accepted by Pope John II in 534, the formulation Unus de Trinitatepassusest carnelOne of the Trinity suffered with in body, assigned to the Scythian monks and summarizing their Christology, was introduced by the emperor Justinian in Confession of faith published in $544^{1}$.

*PhD, Lecturer, "1 Decembrie 1918" University of Alba Iulia (Faculty of Orthodox Theology), Alba Iulia, Romania.

${ }^{1}$ IOn Bria, Dicţionar de Teologie Ortodoxă. A-Z, Bucureşti, Institutul Biblic şi de Misiune al Bisericii Ortodoxe Române, 1994, p. 100. 
Earlier, in 535 or 536, the formulation, although seen with hostility by the bishop Paternus of Tomis and by the pope Hormisdas $^{2}$, was introduced both in The Holy Liturgy and in the hymn You One Born/ 'OMovyevìs. In this hymn, the Christians call

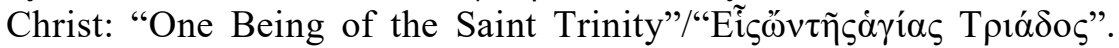
To avoid the Nestorian statement that the humanity added to the Divine Logos by His own will, it is added: "And for our salvation you embraced the incarnate from the Holy Mother always Virgin Mary"; to avoid the idea that Christ is two persons it is stated that $\mathrm{He}$ is "glorified together ( $\sigma v v \delta o \xi \alpha \zeta$ ó $\mu \varepsilon v o \varsigma)$ with the Father and the Holy Spirit". The hymn is also directed against the monophysite heresy, as it is stated that only One of the Trinity was crucified, based on the fact that only He was incarnated as a human; so it was not the case that the whole Trinity was crucified because you cannot worship a Christ-man adjoining the Son or a Trinity Who is a sufferer in Its character ${ }^{3}$.

Starting from the brief presentation of this formulation, we will try to accomplish within this study, a Christological analysis of the ideas stated in it, to elucidate the Christology professed by the so-called Scythian Monks.

The purpose of this endeavour is to show that the Christology professed by the Scythian Monks actually reveals an important aspect of the iconic anthropology; namely, that by assuming human nature in the unique divine hypostasis, Christ not only conjoined this, in a real hypostatic way, to the divine nature, but $\mathrm{He}$ also emphasized the value and the mystery of the human body as an essential factor in the fulfillment of the human within the epectasis ascent of deification. Actually, this is an argument that the later Fatherss of the church (St. John Damascene and St. Theodore the Studite) had in mind when they drew up the theological thinking referring to the possibility of an iconographic representation of the Son of God, of the Holy Mother, of

2 I. G. ComAn, "Şi Cuvântul trup s-a făcut". Hristologie şi Mariologie patristică, Timişoara, Mitropoliei Banatului Ph., 1993, p.172; 245-246; 248-249.

3 D. STĂNiloAe, "Contribuţia călugărilor sciţi la precizarea hristologiei la începutul secolului VI", introductory study to "Scrieri ale 'călugărilorsciţi' daco-romani din secolul al VI-lea (rom.transl. by N. PETRESCU/D. POPESCU), in Mitropolia Olteniei, nr. 3-4/1985, p. 209-210. 
ARS LITURGICA. From the Image of Glory to the Images of the Idols of Modernity

the saints and of the deifying events from the economy of salvation.

\section{A short history of the teopaskit formulation Unus de Trinitatepassusest carne}

Burst in Constantinople in 519 in relation with the teopaskit formulation $^{4}$, the respective quarrel ended only when Pope John II replied in 534. The promoters of this formulation were the so-called Scythian Monks ${ }^{5}$, who wished that the expression One of the Trinity was crucified (suffered in the body) to be used against the Nestorian heresy. But we must mention the fact that in spite of some opinions favourable to a possible link with the monophysical Trisanghion from $488^{6}$, we believe that the use the expression Unus de Trinitate passus est carnelOne of the Trinity suffered in the body is independent from the acceptance of this monophysical trisanghion - "You, Holy God, Almighty God, Immortal God Who were crucified for us, give alms to us" - assigned to Peter Gnafeus (Fullo) 7 . Justinian rejects him but he becomes the promoter of the above mentioned formulation ${ }^{8}$. It is extremely interesting that in his letter Proptitia divinitate sent to Pope Hormisdas, Justinian is not favourable to the Scythian monks and asks the Roman Pontiff to speak out regarding these people ${ }^{9}$. Justinian changes his mind as soon as he notices that the new formulation could reconciliate the Byzantines with the monophysites recreating the religious unity of the empire ${ }^{10}$. So, in other words, the theological

${ }^{4}$ I. G. COMAN, “Şi Cuvântul trup s-a făcut... ”, p. 171.

5 Their names are: Achilles, John, Leontius and Maxentius. See for this D. StăniloAe, "Contribuţia călugărilor sciţi...", p. 199-244.

${ }^{6}$ IOAN G. COMAN, “Şi Cuvântul trup s-a făcut... ”, p. 171; 243.

${ }^{7}$ Ibidem, p. 404-405.

8 PG 86, 1141AB. See also J. PeliKan, Tradiţia creştină. O istorie a dezvoltării doctrinei. I: Naştereatradiţieiuniversale (100-600), rom. transl. by SILVIA PALAdE, Iaşi, Polirom, 2004, p. 282.

9 PL 63, 475: "Sed quoniam comperimus quosdam nomine monachos quibus magis discordia in studio est quam caritas et pax Dei cupientes quaedam perturbare ad angelum vestrum hinc discedentes iter arripuisse: quos beatitudo vestra, praesentibus scriptis causam livoris eorum cognoscens, ita ut merentur, suscipere et a se longe pellere dignetur".

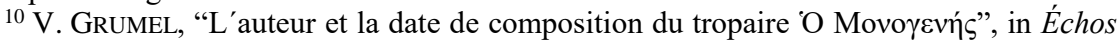
d'Orient. Revue d'histoire et de liturgie orientales, vol. 22, no. 132, Paris/Bucharest, 
formulation had important political connotations, even the destiny of the empire depended on the connotations. A second letter, Quidquid cautius, addressed to Pope Hormisdas, approached this aspect again, this time with direct reference to the Scythian monks ${ }^{11}$.

The third letter, Ut plenisima ${ }^{12}$, approaches the formulation itself, the pope was asked to make a decision on this matter, but the pope did not give an answer. He just expressed his concern regarding this problem in his long letter Sicut rationi, on $13^{\text {th }}$ August 520 to Posessor, an African bishop who had lived in Constantinople since 517. In this letter, he suggested that he is hostile towards the new formulation and this African bishop revealed the same hostility together with the papal deacon Discoros accusing the Scythian monks of monophysism ${ }^{13}$. However, Justinian presents his own opinion in a new letter, received in Rome on $17^{\text {th }}$ September 520, regarding the teopaskit formulation ${ }^{14}$. After all, it was not just an ecclesiastic opportunity but a political one too and the emperor could not let it go.

A last letter from Justinian to Pope Hormisdas Quantum venerationem $^{15}$ - undated, but considering the use of the title consul that Justinian uses for himself it was written probably around the year 521 puts pressure on the latter to give a full answer in order to clarify matters. For this purpose Justinian reconsolidates his position as expressed in the previous letter. Pope Hormisdas expressed his position in letters addressed to Justinian ${ }^{16}$ and to Patriarch Epiphanius of Constantinople ${ }^{17}$ on $25^{\text {th }}$ March 521. He thinks that Calcedon's and Pope Leon's studies and

1932, p. 405.

11 PL 63, 476: "Unde petimus ut, si est possible, cellerimo dato responso et satisfactis religiosis monachis, Joannem et Leontium ad nos remittatis: nisi enim precibus et diligentia vestra ista quaestio soluta fuerit, veremur ne non possit Ecclesiarum sanctarum pax provenire". See atV. GRUMEL, "L'auteur et la date...", p. 405.

12 PL 63, 476: “(...) quid sequi, quidve super hoc evitare debeamus, nos certiorari dignetur ... Hoc enim credimus esse catholicum, quod vestro religioso response nobis fuerit intimatum". See at V. GRUMEL, "L'auteur et la date...", p. 405.

13 I. G. Coman, "Şi Cuvântultrup s-a făcut...”, p. 243-244. See also D. StăniloAe, "Scrieri ale 'călugărilor sciţi' daco-romani din secolul al VI-lea..., p. 14.

${ }^{14}$ V. GRUMEL, "L'auteur et la date...”, p. 406-408.

15 PL 68, 508.

${ }^{16}$ PL 68, 512-515.

${ }^{17}$ PL 68, 515-521. 
advice must be protected and he notes the Roman opposition regarding the acceptance of the formulation of the Scythian monks. There would only be a favourable solution in the time of Pope John II. That is why Justinian delivered an edict of faith, with the bishops' approval, where the formulation Unus de Trinitate was officially approved.

This formulation appeared as a main element of the faith confession which Justinian sent to the Pope by the bishops Hypas and Demetrius and, as in the similar letter addressed to the Patriarch Epiphanius on $26^{\text {th }}$ March 533, both inserted in the Codex ${ }^{18}$. It is the same content that we find in the letter to Epiphanius, of course without the expressions referring to the pre-eminence of the Romans, expressions that Justinian used in order to receive a positive answer from the pope to his demand.

Pope John II's answer ${ }^{19}$ came to Justinian the next year, when the papal delegates returned on April25, 534. Appreciating the emperor's submissiveness, he approved this faith confession without going into details. At the same time, the Pope addressed a letter to the Senators ${ }^{20}$, where, on the basis of Holy Scripture and Holy Fathers, he stated the three main points contained in the confession of faith: a) that Christ is rightly called One in the Holy Trinity, b) that the Virgin Mary is truly God-giving birth and c) that Christ suffered physically, with his body, his divinity remaining unchanged. The pope now insists on the expression Unus de Trinitate, condemning those who opposed $\mathrm{it}^{21}$.

\section{Theology of Scythian monks and its relevance to iconic anthropology}

We must mention from the beginning that the Orthodox Church believes and teaches that the miracles and sufferings of Christ belong to one and the same person, divine, known in two different spheres and

\footnotetext{
18 Justinian, "De summa Trinitate \& fide catholica", Codicis Liber Primus, Tit. IIII, in Codex Iuris Civilis (Codicis Ivstiniani ex repetita praelectione libri novempriores, ex vetvstissimis, et aliis quamplvrimis recentioribvs, exemplaribvs, probatissimisita in vniuersum recogniti, \& emendati, vt nihil praeterea, quod ad puram lectione mattinet, desiderari posit), Lvgdvni, Apud Hugonem a Porta, 1560, p. 11-18.

19 PL 66, 17-20.

${ }^{20}$ PL 66, 20-24.

${ }^{21}$ V. Grumel, "L'auteur et la date...", p. 409.
} 
that Christ, who has suffered with the body, is One in the Holy Trinity by divine nature and One as us, by flesh, by his nature or human nature ${ }^{22}$.

One of the Holy Trinity suffered in the flesh, as the divine Logos, One in the Holy Trinity, Incarnated in the womb of the Virgin Mary, who is the Mother of God. Only in this incarnate situation, of God humanized, One in the Holy Trinity was able to suffer, and not in His report with the other persons of the Holy Trinity ${ }^{23}$. That is why John Maxentiu, the head of the Scythian monks, shows that "if we say that the deity has been crucified, we will bring suffering into the Holy Trinity. If we say that the Logos suffered the passion in His body, we confess that it is 'One of the Trinity' who suffered, and the Trinity remained unassuming. And also, if $\mathrm{He}$ was incarnated and crucified, then the Father and the Holy Spirit were not crucified, but only Him, 'One of the Trinity' was crucified. The deity that is characteristic to the Father and the Holy Spirit remained impassible, but the body suffered"24.

Political and ecclesial events, such as the Akachian schism and Zenon's Henotikon, allowed the use of this formula, although in the Chalcedonian environment it was considered to be intolerable because of a possible monophysical interpretation ${ }^{25}$. The opposition was highlighted, as we have already shown, in Hormisdas' hostile attitude, who believed that the formulation of the Scythian monks attributes the personal properties of the second hypostasis of the Holy Trinity, that is, the Son or the divine Logos, the very essence of the Father, which would have been teopaskism ${ }^{26}$, a teaching that was condemned at the Trulan Synod in 692. However, in a careful investigation, it is noted that this condemnation does not touch the Scythian formulation, but only the addition of Peter Gnafeus to You Holy God, that affirms that God suffered in His divine essence. In the formulation of the Scythian monks, however, it is shown that One in the Holy Trinity, our Lord

\section{Ibidem, p. 414.}

23 V. G. SiBIESCU, "Călugării Sciţi”, in RevistaTeologică, Sibiu, Tiparul Tipografiei Arhidiecezane, 1936, p. 9.

${ }^{24}$ JoAnnisMaXentil, De Christo professio, in PG 86 (I), 82.

${ }^{25}$ I. G. COMAN, “Şi Cuvântul trup s-a făcut... ”, p. 243-244.

${ }^{26}$ V. G. SIBIESCU, op. cit., p. 12. 
Jesus Christ, through incarnation, suffered only in the flesh, suffering which, by virtue of the communications of the attributes of the two beings (divine and human), also affected His person, but not the Most Holy Trinity ${ }^{27}$. The position of the Scythian monks, whose leader was John Maxentius, resided precisely in the resolutions of the Fourth Ecumenical Council of Chalcedon in 451, while supporting the Christology of St. Cyril of Alexandria, especially his 12th Anathema, directed against Nestorius: "If anyone does not confess that the Word of God suffered with the body and was crucified with the body and tasted death with the body and reborn from the dead, because God is life and life creator, be anathema" 28 .

That the Deity did not suffer, Nestorians also stated. They said, however, that God made His own sufferings for His body. But from the Orthodox point of view, the term "own" itself has many meanings, because the Church also said to be the body of Christ, as it is also said that God makes his own sufferings for His Church. Therefore, as John Maxentius shows, there is a voice from heaven that speaks to Saul: "Saul, Saul, why persecutest thou me?" (Acts 9, 4). Thus, sufferings of the body are in a different way proper to the Word. The Nestorians, however, argued that God made His body sufferings more His own, the body with which He had united with, because He united with it as with His garment. But if we were to push the reasoning in this direction, from an Orthodox point of view, we will say that God the Word assumes the sufferings of the body united to Him in a much more intimate way, therefore, He does not unite them in a relationship or morality ( бuvó $\varphi \varepsilon 1 \alpha$ ), for the body in which the Lord suffers is His body and not that of another man. Therefore, it is His own, not being the body of another man united with God, but His own body. If that were not the case, then the Church could not become, even in a lesser degree, the body of Christ, since they would only share the body of a man, united with Christ ${ }^{29}$.

An even clearer position is expressed by Leontius of Byzantium ${ }^{30}$.

${ }^{27}$ Ibidem, p. 23. See also I. G. ComAN, “Şi Cuvântul trup s-a făcut...”, p. 244-245.

${ }^{28}$ C. Voicu/L.-D. Colda, Patrologie, vol. II, Bucureşti, Basilica, 2015, p. 157.

${ }^{29}$ IOAN MAXENȚIU, Dialogi contra Nestorianos, lib. II, PG 86, 145, apud D. STĂNILOAE, "Contribuţia călugărilor sciţi...", p. 212-213.

${ }^{30}$ I. G. COMAN, "Şi Cuvântul trup s-a făcut...”, p. 214. 
This argument, responding to the same objections raised by the Nestorians that God cannot acquire those of the body, with the assertion that if not divinity, then in any case, a divine person can acquire all those his body comes in contact with, so first of all it is about the body things, shows that "the person takes possession of all that happens to his/her body whether natural sufferings, external insults, or any other casualty with Him. Because assuming the body in His own hypostasis, He personalized it" 31 .

As for the term 'own/proper', Leontius of Byzantium also shows its various meanings: "It is the soul's own mind, as power; it is its own thoughts, as works; it is the body as an organ to the soul. It is the man's own son, as being of him; but he also owns an agricultural land as property" 32 . We can see, therefore, that each of these is different as being own, although each refers to the same subject; but this is because of the many meanings of the term 'own'. Being the Christ-God, it is His own body in the most intimate meaning, because he suffered the pain caused by the sufferings of the nails and the spear; on this basis, the Church considers itself as His own body (Ephesians 5, 29; 1 Corinthians $12,27)$. On the other hand, however, the Church and its members are not His body in the most proper sense of the word, because Christ was not crucified in the body of the Church or its members: "The Church is not His own, because He was not nailed up in it... But realize that his body is not proper for the Word nature, but it was done in the latter times proper of His hypostasis" 33 .

As for the monophysical assertion that the body of Christ was not like our actual post-fall body, Leontius states that the Lord took this body, which was not only the first man's, but also ours, because Christ did not come to save only Adam, but the whole human race; therefore, it would be absurd to claim that Christ assumed a body of the same kind only with one, and not with all the others who also needed healing ${ }^{34}$.

31 Adv. Nestor., lib. V, in PG 87 (I), 1748, apud D. STĂNiloAe, "Contribuţia călugărilor...", p. 213.

32 Adv. Nestor., lib. VII, in PG 87 (I), 1765, apud D. STĂniloAe, "Contribuţia călugărilor sciţi...”, p. 213.

${ }^{33}$ Ibidem, p. 213.

34 Contra nestorienilor şi eutihienilor, in PG 86 (I), 1348, apud D. STĂniloAe, "Contribuţia călugărilor sciţi...", p. 213. 
Although God-Word is the hypostasis in which the human nature and the humanity receive its subsistence, he takes so intimately this nature and its work, that without changing from the divine being and without ceasing to remain the divine hypostasis, He also receives the hypostatic attributes of man; therefore, it can be said on one hand that God-the Word is the subject of the human nature and of the human acts (in the sense of Cyril) and on the other hand it can be said in a certain sense that the person of Christ is from the convergence of the property of the two according to Pope Leon's expression in the definition from Calcedon, or that Jesus Christ is both true God and true man. However, Leontius, responding to the Nestorians ${ }^{35}$, refuses to consider the hypostasis of Jesus Christ as a compound, since the new attributes come to belong to the unique hypostasis. In this way, he is a little closer to the Western Christology, without leaving the theology of Cyril, because after him, the hypostasis of the Word attracts its attributes of human hypostasis, depicting the human nature, because the human nature does not give themby its own initiative, as it could be understood from the awkwardness of Pope Leon's expression. The hypostasis of the human nature is still The God-the Word, He being the bearer of the human acts, not a human hypostasis, being the bearer of the divine acts, or a composed hypostasis. So, after the hypostasis, the synthesis of the beings, or their union together was made. However, they did not result in a composed nature, because they did not come together by fusion, nor it is a compound hypostasis, because it is not from hypostases. The property of the hypostasis of the Word became even more uncomposed, piling up more simple properties after the incarnation. This shows that, as His nature is neither changeable nor composed, so is His hypostasis, neither compound nor unchangeable ${ }^{36}$.

What is to be noticed is that Leontius puts great emphasis on the quality of the possessor of the hypostasis. The Word becomes a hypostasis possessor of human nature. The humanity of Christ is not anipostatic, but it does not stand in an independent hypostasis either,

${ }^{35} A d v$. Nestor., lib. VI, in PG 86,1753, apud D. StĂNILOAE, "Definiţia dogmatică de la Calcedon", in Ortodoxia, nr. 2-3/1951, p. 428.

${ }^{36} A d v$. Nestor., lib. VI, in PG 86,1485, apud D. StănIloAe, Definiţia dogmatică..., p. 429. 
because it does not exist in itself. Therefore, in Leontius's conception, between hypostatic and non-hypostatic there is a mediation expressed by enipostasis. This exists in the divine Logos to which it belongs for $\mathrm{He}$ is the one who gives it power to exist, grafting it into Himself ${ }^{37}$. Nestorianism and Monophysitism did not see God-the-Word as needed to work and suffer as a human, because they did not see Him as a divine hypostasis that makes its own human, but as a non-static nature that does not act as a possessor. Giving a Chyrilian conception to the Calcedonian judgments, Leontius will severely criticize the relational and voluntary union of the natures from the Nestorian doctrine - he himself was Nestorian - and rejects their blending or merging in monophysite sense ${ }^{38}$.

The human properties received by the divine hypostasis do not make Him less divine and therefore do not alter His attribute of One in the Trinity ${ }^{39}$. He being One of the Trinity, was born from the Virgin Mary, so in humanity not in Deity; He was put to bed in a manger, by humanity, not by deity; He was hungry by humanity, not by deity; He was tortured, judged, condemned by the wicked, crucified, thrust into the ribs, not by deity but by humanity. He was risen with the body in heaven and is in glory, on the right hand of the Father, being the One who will come again with the body to judge the living and the dead. All these human things God made or suffered as one of the people of the Holy Trinity, but not in His Deity, as the monophysites sustained, but in His humanity. Therefore, they have the unique value and power of salvation. If all these had been suffered by the deity, then He would be mortal, and salvation could no longer be accomplished. On the other hand, if the Person who made and suffered them would not have been One of the Trinity, but a human being, could not have saved us through them. But just as all the human acts mentioned before were made by One of the Trinity by humanity, so all the divine acts were made by $\mathrm{He}$ Who became man but still remaining One in the Trinity ${ }^{40}$.

So, the Divine acts were made in Deity and not in humanity and

${ }^{37}$ I. G. COMAN, “Şi Cuvântul trup s-a făcut... ”, p. 214-216.

38 Ibidem, p. 217.

${ }^{39}$ D. STĂNILOAE, “Contribuţia călugărilor sciţi...”, p. 216.

40 IOAN MAXENȚIU, Altă mărturisire de credinţă, in PG 87 (I), 89-90, apud D. STĂNILOAE, “Contribuţia călugărilor sciţi...”, p. 217. 
this way they were proper for our salvation. It is, therefore, very clear that divinity was not confused with the humanity in the monophysite sense, but it was not separated either from humanity in the Nestorian sense. For this, we can testify that Jesus Christ was born before the eternity from the Father as One of the Trinity, and through Him all the things seen and unseen were made, and without Him nothing was done, but not by his human nature, but by the divine, because "The One and The Same Man is the eternal life, the wisdom, the power of the Father, but not by humanity, but by God; that The One and The Same Man is the image of the Father's existence (...) but not by humanity, but by divinity (...). He was born in flesh, suffered, was crucified, died in flesh. For as $\mathrm{He}$ is One in the Trinity and in the beginning... so the same is from us. And that's why there are not two people of Christ, but one person" ${ }^{41}$.

John Maxentius shows that the Son of God was born without any human seed, from the Virgin Mary womb, "subsisting as God in His own Person" and "remaining as God in His own nature". He did not take from the Virgin a body formed or animated, because in this case this body could have been considered "any man", and in this way Christ would have been the result of a movement from both the divine and the human side. The union of the natures would have been then "social", not "natural". Christ is not, however, an association of two persons, but the Son of God, the bearer of the divine nature and He forms His human nature. Therefore, "the universal faith does not believe or preach that the person of the Word coalesced with the person of any man already formed, but with the nature of the body, and thus teaches that the union accomplished is not social but natural" 42 .

If one were to think that after union, in Christ there is only one nature, the divine, then the divinity of the Word - as John Maxentiu shows - "is not simple, but compound and suffering (...) But to think this about the only deity of Christ is an impiety. Therefore, it remains that the union, which produces composition and avoids simplicity, means the reception of the human nature by the Son of God. And thus,

${ }^{41}$ Ibidem, p. 217-218.

42 IOAN MAXENȚIU, Cuvânt despre unirea Cuvântului cu trupul propriu, in PG 87 (I), 89-92, apud D. STĂNILOAE, “Contribuţia călugărilor sciţi...”, p. 218-219. 
after the union in Christ there are found two natures, of which and in which there is a single Person in Christ" 43 .

Eternal life can flow through The God-the-Word as hypostasis, but He can also suffer with the body. Unless He was crucified and died, He who is Life, then the dead cannot hope for life. The body is life because it is the body of God. Through the flesh, God-the-Word can restrict this outpouring because of His freedom, or He can pour the power from His nature in another way; namely, accepting death in order to defeat it, proving stronger than it. And only if He who is stronger than death accepted this one to defeat it, there will be able to be released from death all those who unite with the One who, being a man, overcame death. In these few premises, we have the saving effect of the form of the Scythian monks that "God suffered with the body. If the body was made proper to God, He Himself was crucified as a Person in His body, as the man as a person suffers in his soul the beatings applied to his body. Not the deity suffers, but it can be said that God suffered in the flesh because Jesus Christ is confessed as a true God" ${ }^{4}$. This is particularly important, as the Holy Trinity is given a special role in Christ's saving economy, centered on the fulfillment of the human by ontological restoration and deification, as decisive factors in outlining the iconic anthropology.

\section{Conclusions}

Taking all these into account, we note that the formulation of the Scythian monks was necessary, because the definition of Calcedon, although affirming that the One and the Same Son, the One-Born is known in the two natures, a priori attributed Him only the birth from human acts ("before the eternity born from the Father by deity, in the latter days [...] of the Virgin Mary, the Mother of God, by humanity") leaving the impression that acts after the appearance of human nature are somehow exclusive of human nature, having nothing to do with the divine nature which the human follows fully, as it will also be stated at

43 Idem, Cărticica împotriva acefalilor, in PG 87 (I), 89-92, apud D. STĂniloAe, “Contribuţia călugărilor sciţi...”,p. 219.

44 Idem, Dialogi contra Nestorianos, lib. II, in PG 87 (I), 142 apud D. STĂniloAe, "Contribuţia călugărilor sciţi...", p. 234. 
ARS LITURGICA. From the Image of Glory to the Images of the Idols of Modernity

the $6^{\text {th }}$ Ecumenical Council (Constantinople, 681). So, it was definitely to be said that the acts after the incarnation were all His: after $\mathrm{He}$ was born as a man, He was also crucified. That is why the Orthodox faith will speak more of the Divine subject accomplishing human acts than of God-the-Word and Christ-man alternatively, like Western theology ${ }^{45}$. In fact, there was inaugurated through this, a theology of neocalcedonic essence $^{46}$.

In this way, the formulation One of the Trinity suffered with the body becomes an argument not only against the Nestorianism, but also against Monophysitism, because if it is not generally said that God suffered in the body, a suffering of all the persons of the Holy Trinity is excluded, in conclusion of what they have in common, of the Divine being. But, in the foundation of their formulation, the Scythian monks are apparently the first to use the clear affirmation that human nature existed in Christ without one's own person, subsisting in His divine hypostasis. In this way, the Calcedonian formulation was defended: a person in two spheres, but in a Chirilic sense, fighting against both Nestorianism and Monophysitism, who did not understand that a nature does not involve an individual ${ }^{47}$.

Summarizing the potential content of Unus de Trinitate passus est carne, the following aspects ought to be distinguished:

a) By appropriating his human nature, One in the Trinity was able to save it from the death, raising this and us, precisely because of the solidarity in this nature, in his eternal communion with the Father and the Holy Spirit. As the hypostasis that has enlightened our nature in Him is immortal, the human nature which He appropriated becomes immortal too. Moreover, even if His death is voluntary, being immortal, $\mathrm{He}$ overcomes death by the Resurrection. As a consequence, we regain immortality, $\mathrm{He}$ being, as the dogmatic definition of the Fourth Ecumenical Council in Calcedon shows, together and within us after humanity ${ }^{48}$.

b) This One in the Trinity, being the Son and the Word of God,

${ }^{45}$ D. Stăniloae, Definitia dogmatică..., p. 422.

46 J. PELIKAN, op. cit., p. 348.

${ }^{47}$ D. STĂniloae, Definiţia dogmatică..., p. 422-423.

${ }^{48}$ Idem, "Introducere", in Scrieri ale 'călugărilor sciţi'daco-romani din secolul al VIlea..., p. 80 . 
becomes also man as the Son of God and the bearer of the Holy Spirit, and we, on the basis of the same solidarity of human nature with Him, become the same. Because of His humanity, the Father's love is directed towards Him as a man too and it is poured for this on ourselves too. At the same time, the love of the Son directed toward the Father becomes our love, on the basis of a common human nature ${ }^{49}$.

c) Through the appropriated humanity, the hypostasis of the Divine Logos as a human, enters into a relationship and direct communication with us, thus communicating to us, endlessly, His divine spiritual riches. At the same time, He appropriates in this way the ways of feeling of all human beings. Thus, God-the-Word, making Himself a hypostasis of the human nature, opens to it, in all the hypostases, the Deity. And human nature is opened to the Divinity by Him, deifying $i^{50}$.

d) The humanity assumed by the Son of God is revealed to have the highest value and eternal value, inseparable from the value of His own Deity, and by attachment to Him, this value is reflected also upon our humanity. In this way, the restored human nature acquires the capacity to reveal, permanently, the spiritual value of God forever ${ }^{51}$.

e) Finally, One of the Trinity, acquiring as a true man our work,our own human nature, as well as His suffering on the part of the whole cosmos, and also our work and suffering in relation to our peers, perfected and confirmed at the same time His position as a center from which, by which and in which everything gravitates, as well as a man working together with us, humans, both in relation to nature and to our peers. Thus, on the basis that he is not only true God, but also true man, the Son of God sees with His human eyes the nature, hears with human ears what people hear and speaks like a man with people, sharing with them the experience occasioned by nature. Thus, man represents the link or the connecting ring between God and the universe, gathering the universe itself to reveal it and fill it with the meanings of its connection with God. That is why the Son of God, as One of the Trinity, only as a man gathered the universe in Himself and lives it with $\mathrm{us}^{52}$.

\footnotetext{
${ }^{49}$ Ibidem, p. 80.

${ }^{50}$ Ibidem, p. 80-81.

51 Ibidem, p. 81.

52 Ibidem, p. 81-82.
} 
If Jesus is One of the Trinity, then the work of the Trinity, which is also of Christ, refers to His body, not to His divine hypostasis. If Christ did not raise up His body, He does not have the power to raise us up either. Accordingly, John Maxentiu observes that "Christ who died for our sins is not alien to the Trinity, but is One of the Trinity Itself. It is created and raised by the whole Trinity not Christ, but undoubtedly the body of Christ, because the body is not another man's, but Christ's Himself. Christ creates and resurrects himself in body together with the Father and the Holy Spirit" 53 .

So the formulation One in the Trinity suffered in the body is perfectly Orthodox. Through this formulation, the Dacian-Roman monks put into being the very value and the mystery of the human body, which, assumed by God, became the body of God-the Word forever, to shine through Him the light and the life of the divinity in the epectatic process of deification ${ }^{54}$. The fulfillment of the human meditated in the spiritual frames of this process is the guarantee and the possibility of the iconographic representation of the Son of God made man, of the Mother of God, of the saints and of the deifying events in the history of the salvation.

\section{References}

1. BRIA, I., Dicţionar de Teologie Ortodoxă. A-Z, Bucureşti, Institutul Biblic şi de Misiune al Bisericii Ortodoxe Române, 1994.

2. Coman, I. G., "Şi Cuvântul trup s-a făcut". Hristologie şi Mariologie patristică, Timişoara, Mitropolia Banatului, 1993.

3. GRUMel, V., "L'auteur et la date de composition du tropaire $\mathrm{O}$

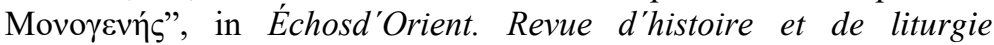
orientales, vol. 22, No. 132, Paris/Bucharest, 1932, p. 398-418.

4. JUstinian, "De summa Trinitate \& fide catholica", Codicis Liber Primus, Tit. IIII, in Codex Iuris Civilis (Codicis Ivstiniani ex repetita praelectione libri novempriores, ex vetvstissimis, et aliis qvamplvrimis recentioribvs, exemplaribvs, probatissimisita in vniuersum recogniti, \& emendati, vt nihil praeterea, quod ad puram lectione mattinet,

${ }^{53}$ IoAn MaXentiu, Dialogi contra Nestorianos, lib. II, in PG 87 (I), 150, apud D. STĂNILOAE, "Contribuţia călugărilor sciţi..." p. 237.

${ }^{54}$ D. STǍNILOAE, “Contribuţia călugărilor sciţi...”, p. 244. 
desiderari posit), Lvgdvni, Apud Hugonem a Porta, 1560, p. 11-18.

5. PeliKan, J., Tradiţia creştină. O istorie a dezvoltării doctrinei. I: Naşterea tradiţiei universale (100-600), rom. transl. by SILVIA PALADE, Iaşi, Polirom, 2004.

6. *** "Scrieri ale 'călugărilorsciţi' daco-romani din secolul al VI-lea", in Mitropolia Olteniei, No. 3-4/1985, p. 245-254.

7. SIBIESCU, V. G., "Călugării Sciţi”, in Revista Teologică, Sibiu, Tiparul Tipografiei Arhidiecezane, 1936.

8. STĂNILOAE, D., "Contribuţia călugărilor sciţi la precizarea hristologiei la începutul secolului VI", introductory study to "Scrieri ale "călugărilor sciţi'daco-romani din secolul al VI-lea, rom. transl. by N. PETRESCU/D. POPESCU, in Mitropolia Olteniei, nr. 3-4/1985, p. 199-244.

9. STĂNILOAE, D., "Introducere la Contribuţia călugărilor sciţi la precizarea hristologiei la începutul secolului VI", in Scrieri ale "călugărilor sciţi" daco-romani din secolul al VI-lea, trad. de N. PETRESCU şi D. POPESCU, Craiova, Mitropolia Olteniei, 2006, p. 5-85.

10. StăniloAe, D., "Definiţia dogmatică de la Calcedon", in Ortodoxia, No. 2-3/1951, p. 295-440. 